\title{
Article \\ A Sustainable Reuse of Agro-Industrial Wastes into Green Cement Bricks
}

\author{
Wei Quan Chin ${ }^{1}$, Yeong Huei Lee ${ }^{1}$, Mugahed Amran ${ }^{2,3, *}{ }^{-}$, Roman Fediuk ${ }^{4,5}{ }^{(}$, Nikolai Vatin ${ }^{5}{ }^{(}$, \\ Ahmad Beng Hong Kueh ${ }^{6}{ }^{-1}$ and Yee Yong Lee ${ }^{6}$
}

check for

updates

Citation: Chin, W.Q.; Lee, Y.H.; Amran, M.; Fediuk, R.; Vatin, N.; Kueh, A.B.H.; Lee, Y.Y. A Sustainable Reuse of Agro-Industrial Wastes into Green Cement Bricks. Materials 2022, 15, 1713. https://doi.org/10.3390/ ma15051713

Academic Editors: F. Pacheco Torgal and P. J. Sánchez-Soto

Received: 16 December 2021

Accepted: 22 February 2022

Published: 24 February 2022

Publisher's Note: MDPI stays neutral with regard to jurisdictional claims in published maps and institutional affiliations.

Copyright: (C) 2022 by the authors. Licensee MDPI, Basel, Switzerland. This article is an open access article distributed under the terms and conditions of the Creative Commons Attribution (CC BY) license (https:// creativecommons.org/licenses/by/ $4.0 /)$.
1 Department of Civil and Construction Engineering, Faculty of Engineering and Science, Curtin University Malaysia, CDT 250, Miri 98009, Sarawak, Malaysia; 700017902@student.curtin.edu.my (W.Q.C.); yhlee@civil.my (Y.H.L.)

2 Department of Civil Engineering, College of Engineering, Prince Sattam Bin Abdulaziz University, Alkharj 16273, Saudi Arabia

3 Department of Civil Engineering, Faculty of Engineering and IT, Amran University, Amran 9677, Yemen

4 Polytechnic Institute, Far Eastern Federal University, 690922 Vladivostok, Russia; fedyuk.rs@dvfu.ru

5 Peter the Great St. Petersburg Polytechnic University, 195251 St. Petersburg, Russia; vatin@mail.ru

6 Department of Civil Engineering, Faculty of Engineering, Universiti Malaysia Sarawak,

Kota Samarahan 94300, Sarawak, Malaysia; kbhahmad@unimas.my (A.B.H.K.); yylee@unimas.my (Y.Y.L.)

* Correspondence: m.amran@psau.edu.sa

\begin{abstract}
The fabrication of bricks commonly consumes relatively high natural resources. To reduce the carbon footprint in the brick production industry, repurposing industrial wastes in the making of sustainable bricks is a recent trend in research and application. Local wastes, such as oil palm shell (OPS), palm oil fuel ash (POFA), and quarry dust (QD), are massively produced annually in the palm oil-exporting countries. Moreover, QD from mining industries is hazardous to both water and air quality. For better waste management in marching towards sustainability, these wastes should be given their second life as construction materials. Therefore, this paper investigates the possibility of incorporating agro-industrial wastes into the brick mixture by examining their properties by means of several standardized tests. For the mix design, a 100\% replacement of coarse aggregate with OPS, $20 \%$ replacement of cement with POFA, 20\% cement weight of limestone as admixture, and 0 to $50 \%$ replacements of fine aggregate with QD are experimentally considered. The optimum mix of these wastes is preliminarily determined by focusing on high compressive strength as an indicator. Other examinations include splitting tensile, flexural strength, water absorption, and efflorescence tests. Although the agro-industrial waste cement brick is $18 \%$ lower in the strength to weight ratio compared to that of conventional, it is observed that it has better late strength development due to its POFA pozzolanic properties. Moreover, the proposed green cement brick is further checked for compliance with several standards for feasible use in the construction industry. Financially, the cost for the brick with the new mix design is almost equivalent to that of conventional. Hence, this green cement brick is reasonable to be employed in the construction industry to promote material sustainability for better waste management.
\end{abstract}

Keywords: agro-industrial waste; POFA; oil palm shell; quarry dust; calcium carbonate; brick

\section{Introduction}

Bricks are common building materials actively applied in the vast majority of construction works. Because of their remarkable features, such as high strength, low production costs, and durability, bricks have played an important role in construction for thousands of years [1-3]. Brick was an important building material in Egypt, Roman, and Mesopotamia [4]. As cement was introduced for concrete binder, clay brick was also innovatively developed into cement brick to reduce the consumption of heating energy that is used to produce clay bricks. Both clay and cement bricks are used in the current 
construction industry. Improving sustainability is one of the most difficult tasks confronting the construction industry, and alternative building materials are being explored to offset environmental impacts and meet standards for sustainable development, manufacturing, and consumption [5,6]. Sustainability supports multifaceted and interdisciplinary collaboration in the building sector to meet human needs, including the requirement for housing, and to organize quality settings for society [7]. Production of bricks is an energy-taxing process that consumes considerable natural resources, namely limestone, clay, gravel, river sand, etc. [8]. In order to remedy this, sustainable materials are in recent years beginning to be introduced as alternatives to conventional brick materials to reduce carbon footprint. Agriculture wastes such as rice husk ash [9,10] and wastewater sludge [11], tannery sludge [12], dust waste [13], etc., are merely some of the numerous materials now considered for this purpose. As one of the largest palm oil-producing countries, Malaysia is found to generate massive wastes in terms of dry mass resulting from the production activity [14], from which great remedial measures must be exercised. Particularly, the identified wastes from the palm oil industry are oil palm shell (OPS) and palm oil fuel ash (POFA), where they can be repurposed as aggregate and cement replacements, respectively, to produce sustainable bricks in matching with the global efforts in improving existing waste management.

The building and demolition industry accounts for $40 \%$ of global energy consumption and one-third of greenhouse gas emissions $[15,16]$. According to reports, as the need for building materials increased, so did the use of raw materials and energy, particularly during the extraction, processing, and material transit phases [17]. The current worldwide volume of solid waste creation is about 2.01 billion tons per year, and it is anticipated to rise to about 3.40 billion tons per year by 2050 [18]. The use of solid industrial waste as substitute stabilizers in building activities has proven to be a viable strategy for decreasing environmental effects while also providing social and economic benefits [19,20]. The worldwide urban growth is one of the primary causes of the significant increase in solid waste output. Emerging nations choose irregular landfill removal and open dumps [21,22]. As a result, it is said, for example, that recycling wastes by incorporating them into construction materials offers a remedy to these concerns concerning the disposal of waste and ecological impact reduction [23]. According to their research, using 1\% cigarette butts into sintered clay bricks can save roughly $10.2 \%$ of the burning energy used in the production process [23].

Because of its mechanical and physical characteristics, as well as the creativity of combining diverse wastes in its manufacturing, the masonry block is one of the most comprehensive building material components [23]. Despite its outstanding workability and availability, it is well known that the manufacturing of sintered masonry blocks has been a very intensive operation in terms of resources and energy, in addition to the significant amounts of carbon consumed [2,24-26]. According to reports, reducing energy usage is a primary emphasis of civil construction [27]. The increased demand for sustainable and environmentally friendly products has prompted research into alternate methods and materials for producing building bricks $[6,28]$. It has also been discovered that the raw materials consumed by the building sector account for an estimated $24 \%$ of the world's raw material supply [29]. Thus, in order to fulfill the maintainable development goal, the choice of construction material is critical. Soil-cement blocks offer a solution to these problems since they are simply created using a procedure that eliminates the need for burning, reduces the amount of cement used, and still allows for the use of waste materials in their composition. Furthermore, the use of cement blocks decreases expenses by up to $40 \%$ when compared to traditional masonry, particularly in low-cost housing [7]. As a result, cement blocks might be deemed more environmentally friendly than typical masonry blocks $[6,30]$.

Natural resource shortages and the formation of solid waste without effective disposal are global concerns [25,31-34], and this permits ecological viability for construction systems, encouraging ecological sustainability and process optimization [35,36]. The current global concerns stem from extensive ecological concerns, as well as the expedited rate of technology innovation in the industry, particularly in construction, and, as a result, attention 
to the concept of alternative building materials, particularly materials produced of the earth, has grown [37]. Because of their poor thermal conductivity, stabilized soil blocks aid increase construction energy efficiency. As a result, they can be used to improve acoustic and thermal insulation in buildings [38]. However, in terms of engineering properties, the abrasion value for OPS is $4.8 \%$, which is the amount of the original oil palm kernel samples ground to smaller than $1.7 \mathrm{~mm}$ diameter, and therefore less likely to deteriorate when used as a base fill [39]. Oil palm shells also have small pores between their fibers that further provide their lightweight characteristic without degradation in strength [40-44]. To date, massive research has been conducted on structural OPS concretes [45-50], where the inclusion of palm oil industry wastes has shown excellent overall concrete properties and durability while incorporating extra advantages of load-carrying characteristics despite being low mass. Moreover, quarry dust (QD) from the mining industry has been identified as useful material for the concrete matrix, attributing to some research on its potential as an aggregate replacement [51-57]. So, QD can be reused in concrete as a building material to reduce the by-product waste disposal into the surrounding environment since severe health issues can be one of the consequences [58].

There is a high demand for cement bricks in the current construction industry, and Malaysia produces tons of waste from industries. In order to incorporate all these local wastes into the concrete matrix and better waste management, this paper investigates, therefore, the design mix feasible to be applied in this proposed green cement bricks towards achieving the aim of manufacturing sustainable construction materials. The main focus is to utilize local all wastes to fully replace coarse aggregate in cement brick which is rarely found in current research trends. To obtain the mechanical properties of the proposed mixes, the experimental program for this study includes compressive, splitting tensile, flexural strengths, water absorption, and efflorescence tests. Additionally, their feasibility as sustainable construction materials is identified through appraisal of compliance with the current local codes. A cost analysis has also been considered comparable to that of conventional to seek its production financial impact. The outcomes should benefit and promote sustainability in the construction industry.

\section{Experimental Investigation}

The current experimental program for studying the feasibility of local wastes for brick production was carried out in three phases. The mixture was designed and identified in Phase 1, properties characterization was performed in Phase 2, while Phase 3 was devoted to the code compliance and cost analysis.

\subsection{Materials}

The identified wastes were POFA, OPS, and QD, where they were, respectively, functioned as the cement, coarse aggregate, and fine aggregate replacements to produce a lightweight concrete mix for brick production.

Additional details for the investigated materials are: Cement-Ordinary Portland cement (OPC), CMC Engineering Sdn Bhd, Selangor, Malaysia; a local product that complied with MS EN 197-1 and ASTM C150; POFA (Curtin University Lab, Sarawak, Malaysia) was considered as the supplementary cementitious material with sizes passing through $45 \mu \mathrm{m}$ sieve and heat-treated at $500{ }^{\circ} \mathrm{C}$; OPS (Malaysian palm oil industry, Sarawak, Malaysia) complied with ASTM C33 for the sizing; QD (quarry dust, Sarawak Malaysia) with the density of $1350 \mathrm{~kg} / \mathrm{m}^{3}$ and sieved to maintain its fineness modulus range of 2.3 to 3.1 (previous properties also have been included in Table 1 as a reference); River sand (Sarawak valley, Malaysia) with the density of $1420 \mathrm{~kg} / \mathrm{m}^{3}$ and passing $4.75 \mathrm{~mm}$ sieve size; superplasticizer of BASF-Master Glenium ACE 8589 type; (MasterGlenium-Master Builders Solutions, Sarawak, Malaysia) and calcium carbonate powder (Supra-coat WCE-22, Shandong Alpa Powder Technology Co., Ltd., Shandong, China) as the admixture to promote early strength to the overall concrete matrix. Figure 1 shows the materials of the design mix. 
Table 1. Physical and chemical properties of QD from previous investigations.

\begin{tabular}{|c|c|c|c|}
\hline \multicolumn{2}{|c|}{ Properties } & [59] & {$[60,61]$} \\
\hline \multirow{4}{*}{ Physical } & Specific gravity & 1.74 & $2.54-2.60$ \\
\hline & Natural water content & $6.59 \%$ & - \\
\hline & Water absorption & $2.34 \%$ & $1.2-1.5 \%$ \\
\hline & Bulk density & $1.55 \mathrm{~kg} / \mathrm{m}^{3}$ & $1720-1810 \mathrm{~kg} / \mathrm{m}^{3}$ \\
\hline \multirow{9}{*}{ Chemical } & $\mathrm{SiO}_{2}$ & - & $62.48 \%$ \\
\hline & $\mathrm{Al}_{2} \mathrm{O}_{3}$ & - & 18.72 \\
\hline & $\mathrm{Fe}_{2} \mathrm{O}_{3}$ & - & 6.54 \\
\hline & $\mathrm{CaO}$ & - & 4.83 \\
\hline & $\mathrm{MgO}$ & - & 2.65 \\
\hline & $\mathrm{Na}_{2} \mathrm{O}$ & - & - \\
\hline & $\mathrm{K}_{2} \mathrm{O}$ & - & 3.18 \\
\hline & $\mathrm{TiO}_{2}$ & - & 1.21 \\
\hline & Loss of ignition * & - & 0.48 \\
\hline
\end{tabular}

* Loss of ignition is the weight loss of a sample after thermal treatment (heating/firing) at high temperature, normally $1000^{\circ} \mathrm{C}$, and $1 \mathrm{~h}$ of soaking time.
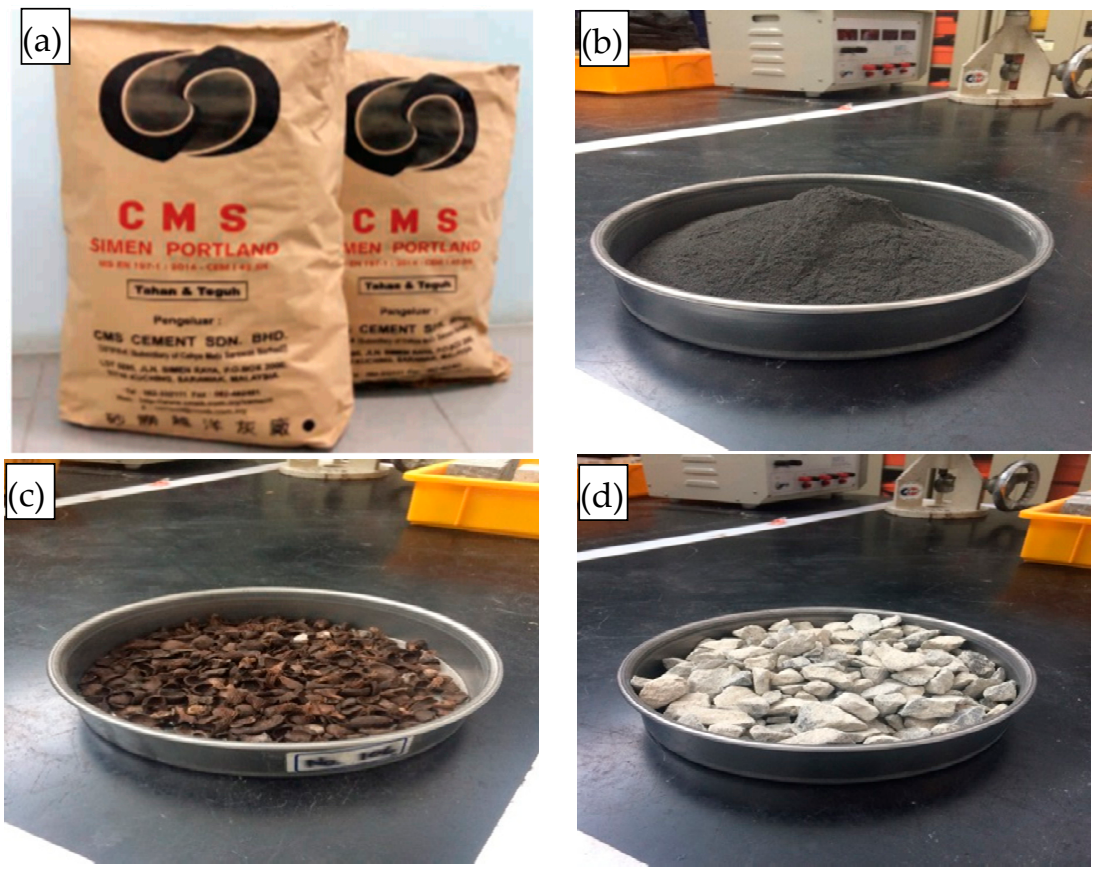

Figure 1. Materials used in the design mix, (a) OPC, (b) POFA, (c) OPS and (d) gravels.

\section{Particle Size Distribution}

The main purpose of the sieve analysis was to determine the particle size distribution for each material used to cast the concrete in complying with the ASTM C330M [62] and C33M [63] standards. Several fine aggregate mixtures were proposed and tabulated in Table 2, where only the mix with $50 \%$ of QD and $50 \%$ of river sand grading followed the ASTM C33M requirement. The coarse aggregate grading is shown in Figure 2 for gravel and OPS. Both aggregates can pass through the nominal diametric sieve size of $4.75 \mathrm{~mm}$. 
Table 2. Fineness modulus and classification of fine aggregate.

\begin{tabular}{cccc}
\hline Mixing Proportion & $\begin{array}{c}\text { Fineness } \\
\text { Modulus }\end{array}$ & Classification & $\begin{array}{c}\text { Compliance to ASTM } \\
\text { C33M Grading System }\end{array}$ \\
\hline $100 \%$ RS & 0.993 & Fine Sand & Not complied \\
$100 \%$ QD & 3.741 & Coarse Sand & Not complied \\
$10 \%$ QD + 90\% RS & 1.312 & Fine Sand & Not complied \\
$30 \%$ QD + 70\% RS & 1.612 & Fine Sand & Not complied \\
$50 \%$ QD + 50\% RS & 2.562 & Well Graded Sand & Complied \\
\hline
\end{tabular}

$\mathrm{RS}=$ river sand, $\mathrm{QD}=$ quarry dust.

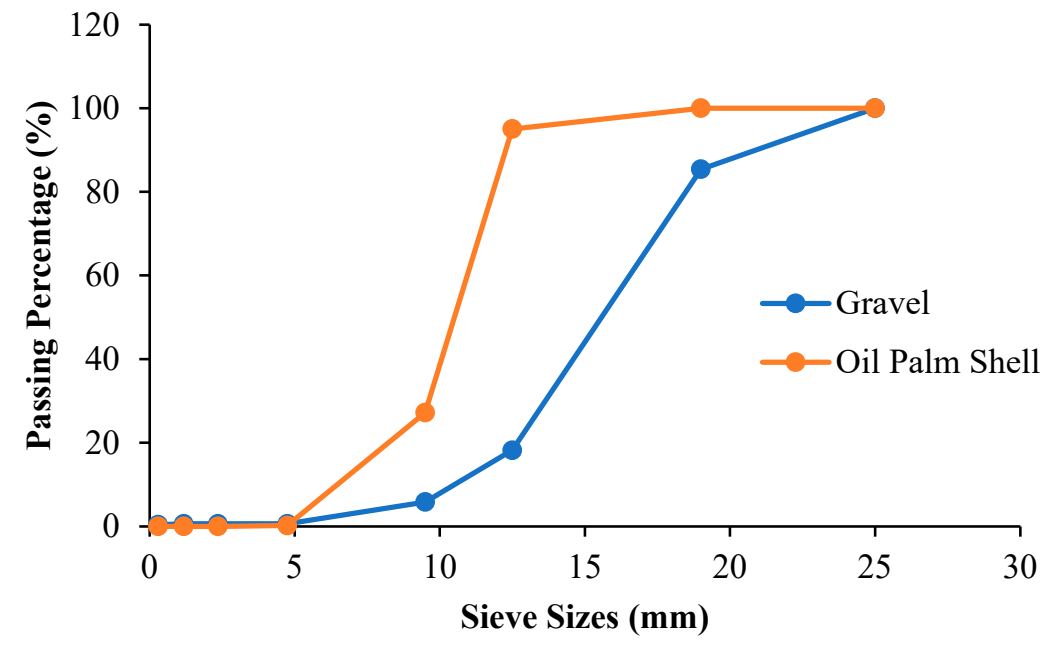

Figure 2. Comparison of the coarse aggregate grading of gravel and OPS.

\subsection{Mix Design}

The mix design was fixed at 1:1:1 for cement, fine, and coarse aggregates according to [39]. In Phase 1, an identical mix of binder ( $80 \%$ OPC $+20 \%$ POFA), coarse aggregate $(100 \%$ OPS $)$, and fine aggregate $(50 \%$ QD $+50 \%$ RS) were considered with the watercement ratio and superplasticizer content as variables. From the preliminary study, both water-cement ratios of 0.45 and 0.5 were acceptable, while a $1 \%$ cement weight of the superplasticizer was determined as meeting the program objective in this stage. The mixes were able to flow with total slump, and the compressive strength exceeded $17 \mathrm{MPa}$ of structural use. The equivalent weight of limestone powder with POFA was added to the mixture to activate the reaction of POFA. In Phase 2, 10\%, 30\%, and 50\% QD were examined along with the consideration of a control case of conventional concrete specimen for comparison. Table 3 shows the preliminary design mix in Phase 1. Table 4 shows the mix design of Phase 2.

Table 3. Summary of mix design (1 cement: 1 coarse aggregate: 1 fine aggregate) and proportion distribution for Phase 1.

\begin{tabular}{cccccccccc}
\hline & \multicolumn{2}{c}{ Binder } & \multicolumn{2}{c}{ Coarse Aggregate } & Fine Aggregate & \multicolumn{2}{c}{ Admixture } & $\begin{array}{c}\text { Water } \\
\text { Sample }\end{array}$ \\
\cline { 2 - 9 } & Cement (\%) & POFA (\%) & Gravel (\%) & OPS (\%) & Sand (\%) & QD (\%) & SP (\%) & $\begin{array}{c}\text { Limestone } \\
\text { (\% of } \\
\text { Cement) }\end{array}$ & $\begin{array}{c}\text { Cement } \\
\text { Ratio }\end{array}$ \\
\hline 1 & 80 & 20 & 0 & 100 & 50 & 50 & 0.5 & 20 & 0.45 \\
2 & 80 & 20 & 0 & 100 & 50 & 50 & 0.5 & 20 & 0.5 \\
3 & 80 & 20 & 0 & 100 & 50 & 50 & 1.0 & 20 & 0.45 \\
4 & 80 & 20 & 0 & 100 & 50 & 50 & 1.0 & 20 & 0.5 \\
\hline
\end{tabular}


Table 4. Summary of mix design and proportion distribution for Phase 2.

\begin{tabular}{cccccccc}
\hline & \multicolumn{2}{c}{ Binder } & Coarse Aggregate & Fine Aggregate & Admixture \\
\cline { 2 - 7 } Specimen & Cement (\%) & POFA (\%) & Gravel (\%) & OPS (\%) & Sand (\%) & QD (\%) & $\begin{array}{c}\text { Limestone } \\
\text { SP (\%) of } \\
\text { Cement) }\end{array}$ \\
\hline Control & 100 & 0 & 100 & 0 & 100 & 0 & 0 \\
100\% RS & 80 & 20 & 0 & 100 & 100 & 0 & 1 \\
$10 \%$ QD + 90\% RS & 80 & 20 & 0 & 100 & 90 & 10 & 1 \\
$30 \%$ QD + 70\% RS & 80 & 20 & 0 & 100 & 70 & 30 & 1 \\
$50 \%$ QD + 50\% RS & 80 & 20 & 0 & 100 & 50 & 50 & 20 \\
\hline
\end{tabular}

\subsection{Methods of Testing}

In the following, the conducted tests for the characterization of the concrete specimens are described. All specimens were tested according to test procedures in codes of practice. Only one specimen was tested for slump, density, efflorescence, and water absorption tests. However, average values of three specimens were obtained from the strength tests.

\subsubsection{Slump Test and Density}

Slump tests were carried out in accordance with ASTM C143 [64]. Three layers of the mix were poured to fill up the cone alongside the application of 25 times compaction with the rod tamps for each layer. The cone was then removed without lateral and torsional movements such that the slump height was measured immediately after the removal of the cone. Additionally, the fresh density was measured by weighing the specimen in a cube after 15 min of compaction on three layers of mix according to ASTM C172 [65]. The dry density was determined by weighing the specimen at concrete testing age of 28 days.

\subsubsection{Strength Test}

Compressive strength was determined according to ASTM C140 [66] at 7, 14, 21, and 28 days of concrete ages for specimens prepared with a $100 \mathrm{~mm}$ cube, as shown in Figure 3. Three specimens were prepared for each of the concrete ages with a loading rate of $0.4 \mathrm{MPa} / \mathrm{min}$. For concrete tension strength, the splitting tensile test was carried out according to the code specifications of ASTM C496 [67]. For this, three cylindrical specimens for each of the concrete ages, with dimensions of $200 \mathrm{~mm}$ height and $100 \mathrm{~mm}$ diameter, were tested under a loading rate of $1.0 \mathrm{MPa} / \mathrm{min}$. Furthermore, a flexural strength test was conducted for all mixes based on ASTM C78 [68] at 28 days of concrete age using three prepared specimens.

\subsubsection{Efflorescence and Water Absorption Tests}

At the concrete curing age of 28 days, efflorescence and water absorption tests were carried out according to the ASTM specifications $[66,69]$. Only one specimen was prepared for concrete curing ages of 7 and 28 days. The bricks (with size of $215 \times 100 \times 65 \mathrm{~mm}$ ) were placed on their header faces towards the ground in distilled water for seven days after the end of the curing session of 28 days, as shown in Figure 4 . The bricks were next heated after the 7 -days immersion at $110{ }^{\circ} \mathrm{C}$ for $24 \mathrm{~h}$. Then, they were placed at $3 \mathrm{~m}$ away from the observer for the examination of any sign of efflorescence at any face of the brick. Any white residue in the distilled water tank was also observed, i.e., looking for any sign of efflorescence or precipitation of mineral salt within the concrete matrix. For the water absorption test, the specimens were oven-dried for $24 \mathrm{~h}$ at $110^{\circ} \mathrm{C}$ and then immersed in water. Both dry and wet weights were measured to quantify the water absorbance of the specimens. 

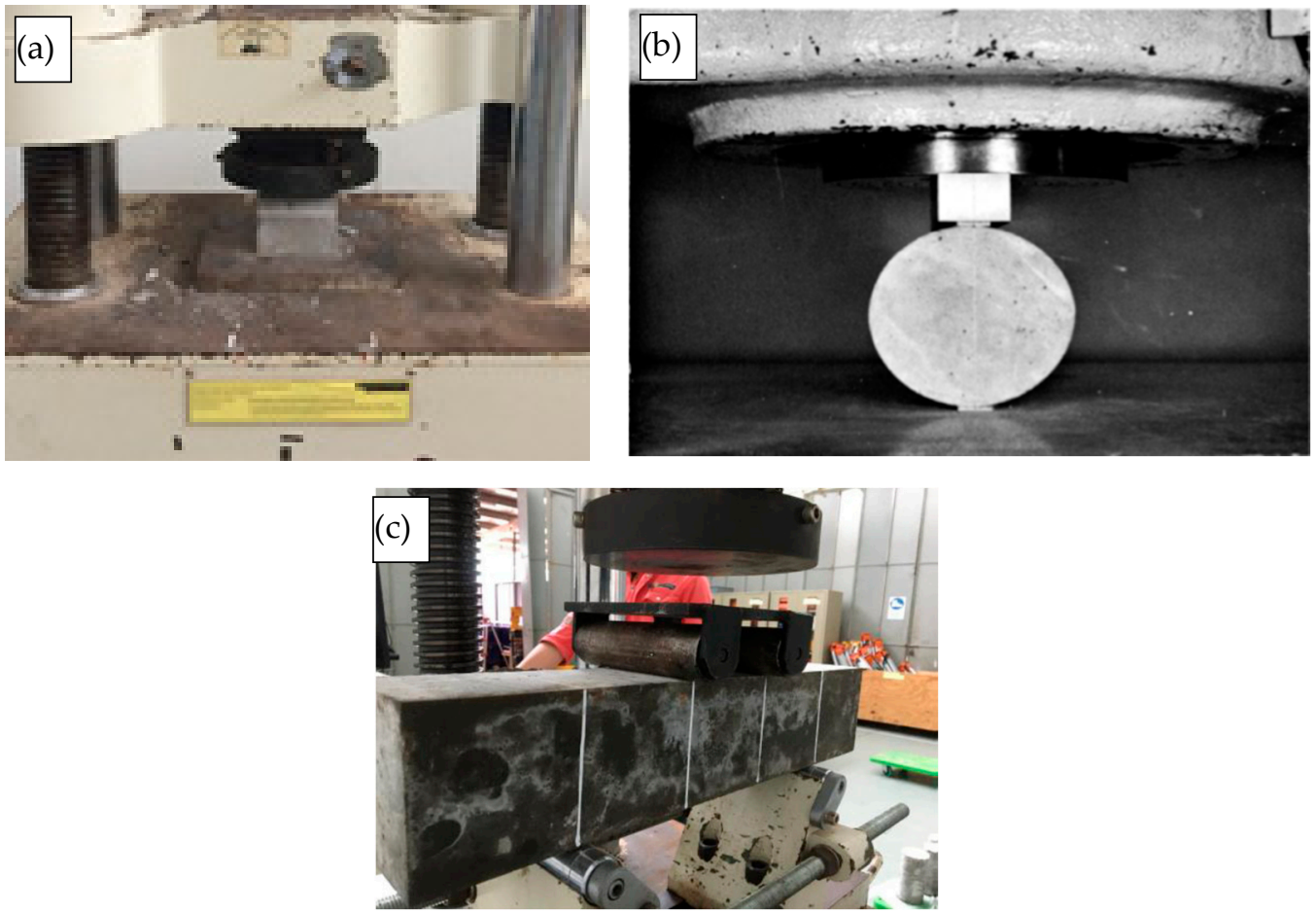

Figure 3. (a) compression (b) splitting tensile and (c) flexural tests setup.

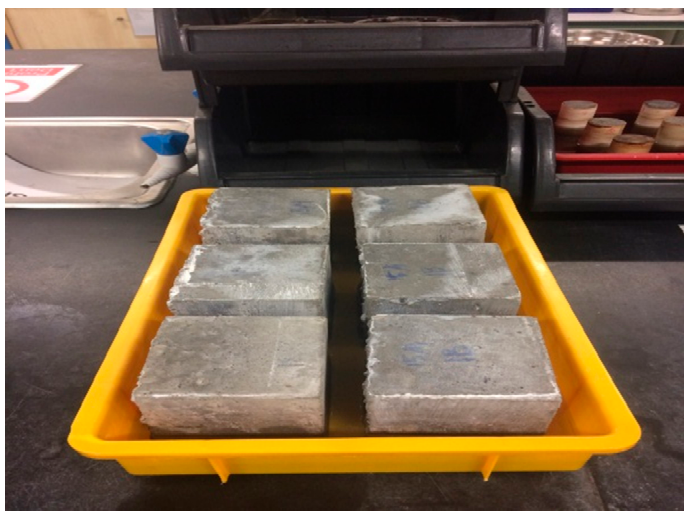

Figure 4. Immersion for efflorescence test.

\section{Results and Discussions}

From Phase 1, the optimum superplasticizer was determined at $1 \%$ of the cement weight with a water-cement ratio of 0.45 . This was then applied in Phase 2 investigation for various fine aggregate replacements with different proportions of QD. The properties of the design mixes in Phase 2 are discussed in detail in the following sections.

\subsection{Densities and Slump Properties}

From Table 5, the densities of $100 \%$ RS are found to be $25.7 \%$ and $29.6 \%$ lighter than the conventional concrete mixes for fresh and dry densities, respectively. The differences are due to the POFA content replacement of $20 \%$ of cement weight. The various replacements with QD show no significance in the fresh or oven-dry densities, with only a slight decrease in densities for higher replacement contents. Compared to conventional concrete, the computed highest reduction in the total dead load coming from the construction material is $35.0 \%$. This will eventually help to reduce the transportation cost of material and also fulfilling the supporting members' dimension needs. In the context of performance, almost all mixes achieve more than $17 \mathrm{MPa}$ at 28-days of the characteristic concrete strength. The 
workability of all specimens is considered to have a high slumping value as the range is 209 to $231 \mathrm{~mm}$.

Table 5. Slump results and density measurements for the design mix.

\begin{tabular}{|c|c|c|c|c|c|}
\hline Concrete Sample & $\begin{array}{l}\text { Fresh Density, } \\
\mathrm{kg} / \mathrm{m}^{3}\end{array}$ & Slump (mm) & $\begin{array}{c}\text { Slump } \\
\text { Characteristic }\end{array}$ & $\begin{array}{c}\text { Oven-Dried } \\
\text { Density, } \mathrm{kg} / \mathrm{m}^{3}\end{array}$ & $\begin{array}{l}\text { Performance Index, } \\
\text { MPa in a Unit Density }\end{array}$ \\
\hline $100 \%$ RS & 1864 & 231 & Total Slump & 1653 & 20.99 \\
\hline $10 \%$ QD + $90 \%$ RS & 1840 & 228 & Total Slump & 1622 & 21.58 \\
\hline $30 \% \mathrm{QD}+70 \% \mathrm{RS}$ & 1837 & 217 & Total Slump & 1617 & 22.11 \\
\hline $50 \%$ QD + 50\% RS & 1821 & 209 & Total Slump & 1587 & 17.33 \\
\hline Control & 2343 & 107 & True Slump & 2143 & 25.28 \\
\hline
\end{tabular}

\subsection{Mechanical Properties}

\subsubsection{Compressive Strength}

From Table 6, it is witnessed that the obtained compressive strengths can be categorized as structural concrete according to the ACI code specification of $17 \mathrm{MPa}$ for both cube and brick size specimens. All specimens display a customary increasing trend in strength following the increase in the curing time. Additionally, the corresponding typical failure mode is shown in Figure 5. It can also be noticed in Table 5 that the increment of quarry dust replacement does not cause any effects on the strength gain throughout the curing ages.

Table 6. Strength at different concrete ages.

\begin{tabular}{ccccccccc}
\hline & \multicolumn{9}{c}{ Compressive Strength (MPa) } \\
\cline { 2 - 9 } Specimen & \multicolumn{9}{c}{ Cube } & \multicolumn{3}{c}{ Brick } \\
\cline { 2 - 9 } & 7 Day & 14 Day & 21 Day & 28 Day & 7 Day & 14 Day & 21 Day & 28 Day \\
\hline 100\% RS & 22.25 & 29.13 & 33.83 & 34.70 & 21.80 & 31.10 & 34.15 & 34.76 \\
10\% QD + 90\% RS & 22.25 & 26.42 & 33.00 & 35.00 & 26.22 & 38.41 & 39.63 & 43.60 \\
30\% QD + 70\% RS & 25.20 & 29.33 & 33.33 & 35.75 & 25.13 & 26.83 & 29.88 & 47.56 \\
$50 \%$ QD + 50\% RS & 21.54 & 22.71 & 25.17 & 27.50 & 28.66 & 33.54 & 38.72 & 45.73 \\
Control & 39.24 & 40.45 & 44.55 & 54.17 & 56.71 & 57.32 & 76.83 & 77.44 \\
\hline
\end{tabular}
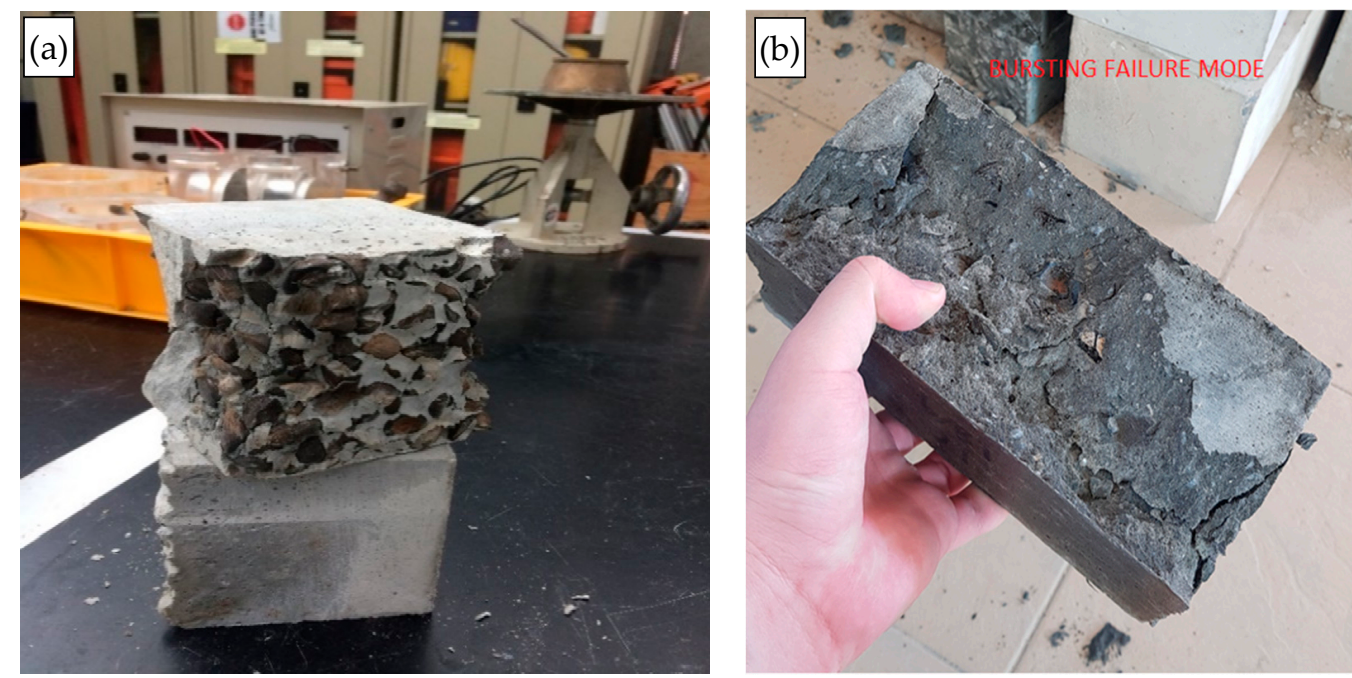

Figure 5. Typical failure modes of the design mixes for (a) cube and (b) brick specimens.

From the test observation, due to the low specific gravity of OPS, the design mixes showed tendency to segregate thereby potentially affecting their compressive strength [70]. Compared to previous similar mixes [71], the current finding showed an improvement of 
strength with the limestone powder inclusion. The filler effects of the limestone powder inflicted the hydration reaction to take place at optimum cement exposure with added water and hence promoting the strength development [72]. Moreover, ettringite was formed when applying limestone in the concrete matrix, which makes the concrete more durable [73].

It can be seen in Table 6 that the growth of compressive strength up to 28-days of concrete age for $30 \% \mathrm{QD}+70 \% \mathrm{RS}$ is $29.8 \%$, where it is only $27.5 \%$ for the control sample. The incorporation of POFA promotes strength development at a later concrete age with additional pozzolanic reaction because the pozzolanic activity can consume the calcium hydroxide in the interfacial transition zone (ITZ) to improve the binding of concrete with the aggregates. The calcium hydroxide usually resides in the area where concrete and the aggregates meet [74]. Furthermore, the hydroxide compounds commonly need a longer time to form C-S-H and C-A-H gels, which promotes later strength. These reactions concur with the addition of POFA into the concrete matrix due to its mineral composition and pozzolanic properties $[40,75]$. The $\mathrm{SiO}_{2}$ in POFA can react with the $\mathrm{Ca}(\mathrm{OH})_{2}$ from cement hydration to produce extra C-S-H bonding [76].

\subsubsection{Splitting Tensile Strength}

Table 7 summarizes that only 30\% QD + 70\% RS achieves the structural requirement of $2 \mathrm{MPa}$ specification from the laboratory results. The splitting tensile strength displays the same enhancement trend as that depicted by the compressive strength, where the increment in compressive strength offers a positive effect on the tensile strength. There were several published equations used for the correlation of the splitting tensile based on the compressive strength of the concrete at specified concrete age. These include Equation (1) [39] for OPS as the replacement for coarse aggregate, Equation (2) for conventional concrete mixes [77], Equation (3) for lightweight concrete with densities between 1600 and $1860 \mathrm{~kg} / \mathrm{m}^{3}$ [78], and Equation (4) for fly ash as cement replacement [79]. Making a comparison with Table 6, Equation (3) is observed to display the most identical result with that of actual as gathered from the laboratory test. From Table 7, Equations (3) and (4) can be used to predict the empirical tensile strength of OPS and expanded clay concrete.

$$
\begin{gathered}
f_{t}=0.4887 \sqrt{f_{c u}} \\
f_{t}=0.2 f_{c y}^{0.7} \\
f_{t}=0.297 \sqrt{f_{c y}} \\
f_{t}=0.58 \sqrt{f_{c y}}
\end{gathered}
$$

where $f_{t}$ is the splitting tensile strength, $f_{c u}$ is the characteristic compressive strength, $f_{c y}$ is the compressive strength (concrete age is not specified).

\subsubsection{Flexural Strength}

As summarized in Table 7, the three-point flexural test results also show a similar enhancement trend with those of compressive and tensile strengths. The typical failure can be found in Figure 6, which initiate by cracking. The flexural strength increased when the substitution of sand with quarry dust proportion was increased up to $30 \%$. When the quarry dust reached $50 \%$, the flexural strength tended to perform adversely when compared to those with lesser replacement. This observation matches with that of the previous investigation, which showed that $40 \%$ of sand replacement by QD was the optimum design mix [80]. 
Table 7. Splitting tensile strength and flexural strength for concrete specimens with different curing periods.

\begin{tabular}{|c|c|c|c|c|c|c|c|c|c|c|}
\hline \multirow{2}{*}{ Sample } & \multicolumn{5}{|c|}{ Splitting Tensile Strength (MPa) } & \multicolumn{5}{|c|}{ Flexural Strength (MPa) } \\
\hline & Actual & $\begin{array}{l}\text { Equation } \\
\text { (1) }\end{array}$ & $\begin{array}{l}\text { Equation } \\
\text { (2) }\end{array}$ & $\begin{array}{l}\text { Equation } \\
\text { (3) }\end{array}$ & $\begin{array}{c}\text { Equation } \\
(4)\end{array}$ & Actual & $\begin{array}{l}\text { Equation } \\
\text { (5) }\end{array}$ & $\begin{array}{l}\text { Equation } \\
(6)\end{array}$ & $\begin{array}{l}\text { Equation } \\
\text { (7) }\end{array}$ & $\begin{array}{l}\text { Equation } \\
(8)\end{array}$ \\
\hline $100 \%$ RS & 1.814 & 2.881 & 2.397 & 1.751 & 1.419 & 3.236 & 3.195 & 3.080 & 4.899 & 3.419 \\
\hline $10 \% \mathrm{QD}+90 \% \mathrm{RS}$ & 1.979 & 3.227 & 2.810 & 1.961 & 2.830 & 3.512 & 3.716 & 3.450 & 5.698 & 3.830 \\
\hline $30 \% \mathrm{QD}+70 \% \mathrm{RS}$ & 2.067 & 3.370 & 2.986 & 2.048 & 3.000 & 4.322 & 3.938 & 3.603 & 6.038 & 4.000 \\
\hline $50 \%$ QD + 50\% RS & 1.895 & 3.305 & 2.905 & 2.008 & 2.922 & 2.761 & 3.836 & 3.533 & 5.883 & 3.922 \\
\hline Control & 3.423 & 4.301 & 4.201 & 2.613 & 4.104 & 5.501 & 5.450 & 4.598 & 8.357 & 5.104 \\
\hline $\begin{array}{l}\text { Two-tailed } p \text { value } \\
\text { Paired } t \text { test at } 95 \% \\
\text { confidence level }\end{array}$ & - & 0.0002 & 0.0003 & 0.3895 & 0.0757 & - & 0.5510 & 0.5077 & 0.0014 & 0.5373 \\
\hline $\mathrm{t}$ & - & 12.5696 & 11.4369 & 0.9643 & 2.3833 & - & 0.6502 & 0.7266 & 7.8173 & 0.6740 \\
\hline$d f$ & - & 4 & 4 & 4 & 4 & - & 4 & 4 & 4 & 4 \\
\hline $\begin{array}{l}\text { Standard error of } \\
\text { difference }\end{array}$ & - & 0.094 & 0.072 & 0.165 & 0.260 & - & 0.247 & 0.294 & 0.295 & 0.280 \\
\hline difference & - & $\begin{array}{r}\text { statistically } \\
\text { significant }\end{array}$ & $\begin{array}{l}\text { statistically } \\
\text { significant }\end{array}$ & $\begin{array}{c}\text { not } \\
\text { statistically } \\
\text { significant }\end{array}$ & $\begin{array}{c}\text { not } \\
\text { statistically } \\
\text { significant }\end{array}$ & - & $\begin{array}{l}\text { not } \\
\text { statistically } \\
\text { significant }\end{array}$ & $\begin{array}{c}\text { not } \\
\text { statistically } \\
\text { significant }\end{array}$ & $\begin{array}{r}\text { statistically } \\
\text { significant }\end{array}$ & $\begin{array}{c}\text { not } \\
\text { statistically } \\
\text { significant }\end{array}$ \\
\hline
\end{tabular}

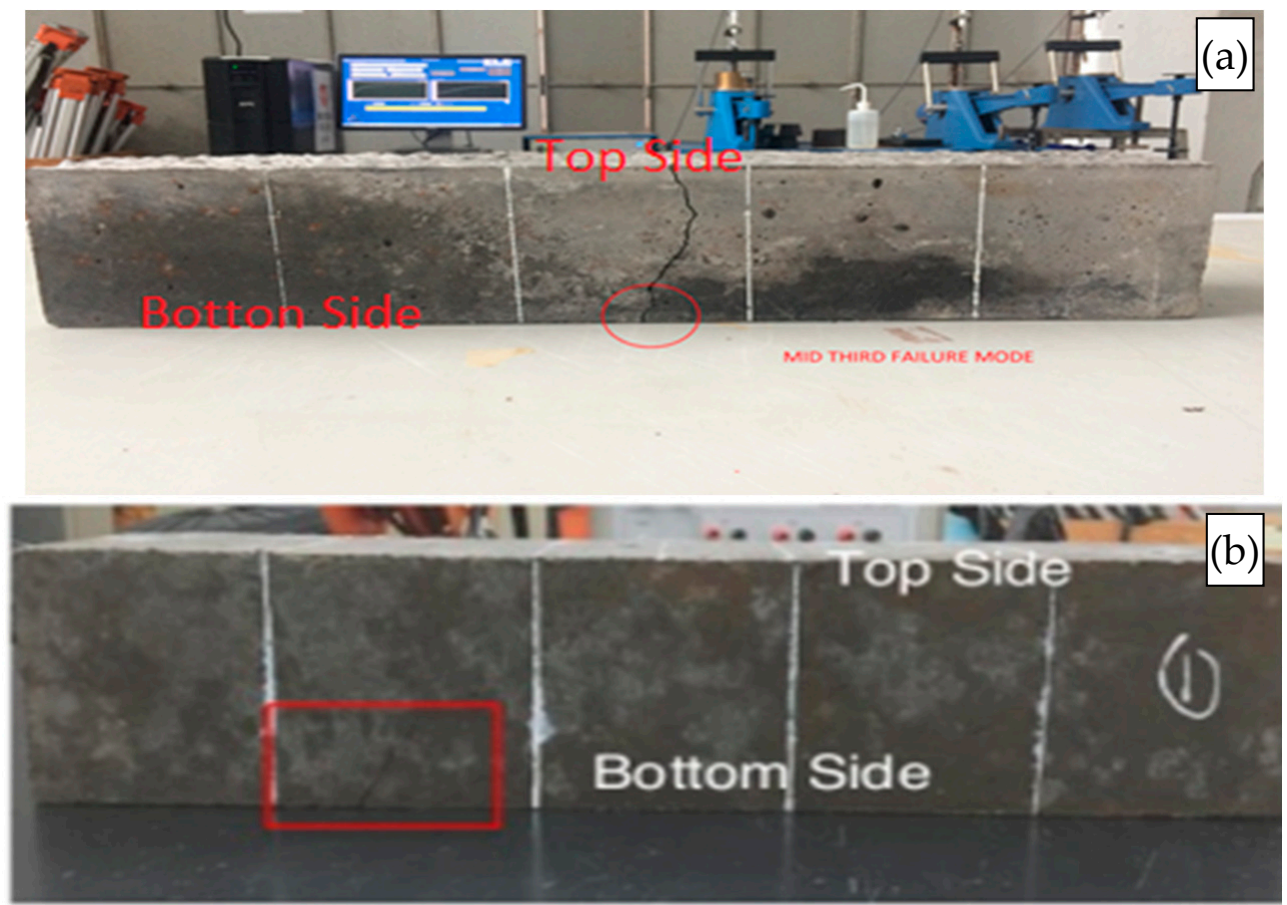

Figure 6. Typical failure of flexural test: (a) within central region and (b) outside central region.

Several equations are readily available to estimate the flexural strength, including Equation (5) for OPS concretes and Equations (6)-(8) for lightweight concretes:

$$
\begin{gathered}
f_{r}=0.3 \sqrt[3]{f_{c u}^{2}} \\
f_{r}=0.5225 \sqrt{f_{c u}} \\
f_{r}=0.46 \sqrt[3]{f_{c u}^{2}} \\
f_{r}=0.58 \sqrt{f_{c u}}
\end{gathered}
$$

where $f_{r}$ is the flexural strength, $f_{c u}$ is the characteristic compressive strength.

From Table 7, Equations (5), (6) and (8) can be used to predict the empirical flexural strength of OPS and expanded clay concrete. However, Equation (5) demonstrates the most 
identical prediction values in the cases of the full sand replacement with QD and control specimens. There is not solely one equation that predicts well the flexural strength of all the proposed design mixes. Hence, a further correlation should be established for more accurate strength prediction in the absence of laboratory results.

\subsubsection{Water Absorption}

Figure 7 shows that the addition of OPS and more content of QD enhances the water absorption ability of the mixture. OPS may absorb 36\% more water than conventional gravel concrete, according to a previous investigation [81]. Lower water absorption was found in the current research as OPS were pre-soaked before mixing with concrete resulting in lower water absorbance tendency.

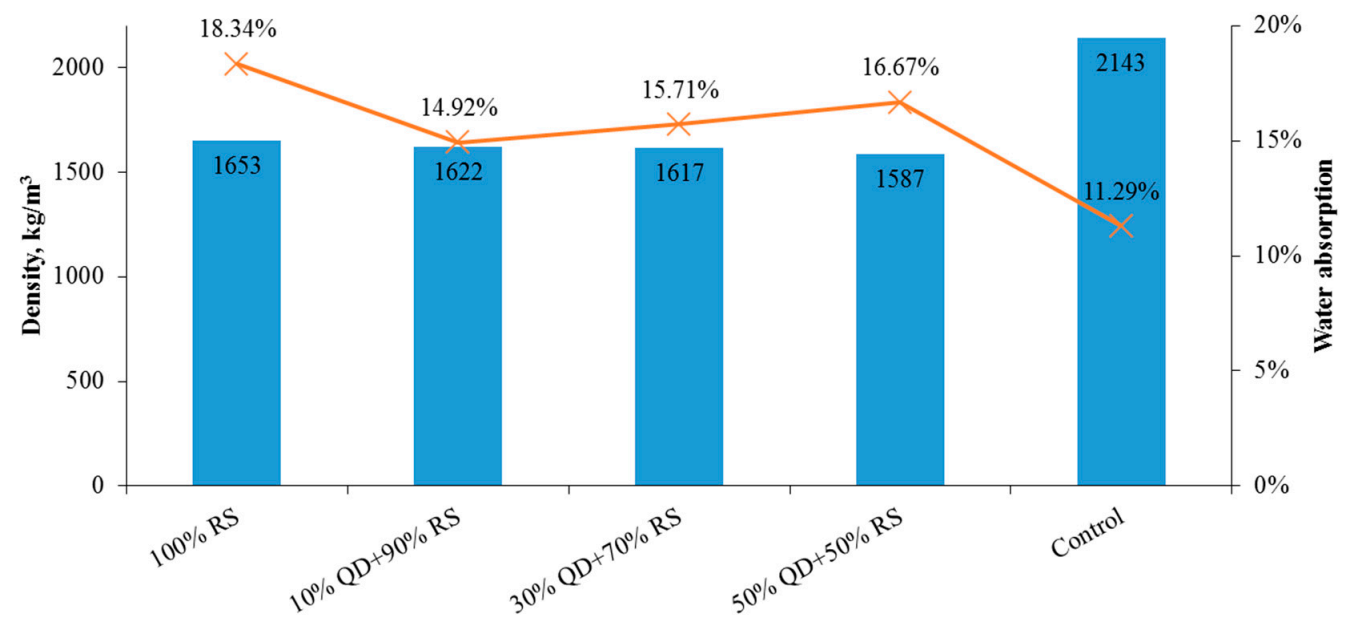

Figure 7. Water absorption of the design mix.

\subsubsection{Efflorescence Test}

All specimens were effloresced where a layer of mineral salt precipitation was noticed on their immersed surfaces, as shown in Figure 8. The primary type of salt formed on the specimens was calcium carbonate, which came from the unreacted $\mathrm{Ca}(\mathrm{OH})_{2}$ from the hydration. $\mathrm{Ca}(\mathrm{OH})_{2}$ was transported out to the $25 \mathrm{~mm}$ distilled water layer as the salt content was lower in the distilled water. After the immersion process, the samples were taken out and dried, during which the precipitation happened as $\mathrm{Ca}(\mathrm{OH})_{2}$ was in contact with carbon dioxide to form $\mathrm{CaCO}_{3}$.

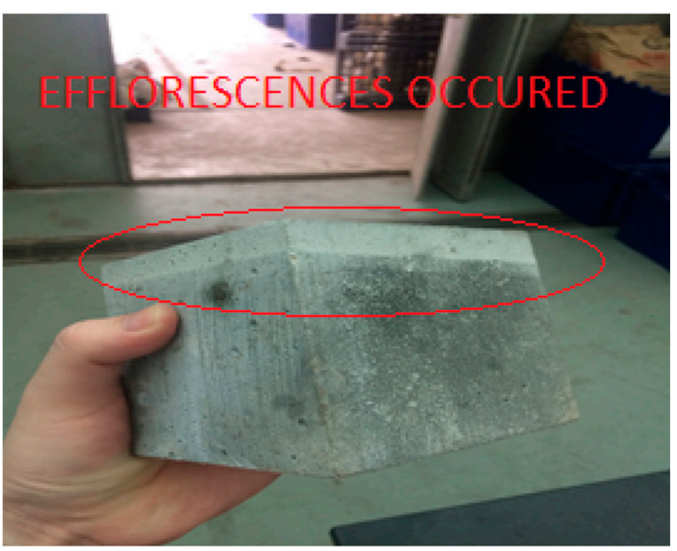

Figure 8. Calcium carbonate deposition layer on the specimen.

Specimens with limestone powder may cause extra precipitation due to the reaction of $\mathrm{Ca}(\mathrm{OH})_{2}$ in the concrete matrix with the pozzolans (POFA) to form C-S-H gels and thereby 
increase the density of the concrete while pushing out the excess insoluble $\mathrm{CaCO}_{3}$ through the capillaries of the concrete. As the specimens with limestone powder experienced two phases of precipitation, it is justified that the efflorescence visibility was more obvious as compared to the control specimen.

\subsection{Effects of Drying Shrinkage}

Drying shrinkage is one of the most common issues in the concrete industry attributed to its deteriorating effects on concrete strength. Drying shrinkage can be caused by the type of aggregate used, concrete rigidity, water-cement ratio, curing method, environment, etc. According to [82], the normal-weight concrete has a lower drying shrinkage than lightweight concrete, and this is mainly due to the properties and quantities of the aggregate [83]. OPS tends to have a higher water absorption rate than conventional gravel in the concrete matrix [84]. The smooth surface of OPS, with a lower specific surface area as compared to gravel, contributes to the higher drying shrinkage [85]. A lower water-cement ratio may minimize the drying shrinkage, as it has a low possibility of excessive water evaporation [86]. In turn, the minimization of the drying shrinkage may promote the concrete strength.

A higher replacement of quarry dust requires a larger amount of water for the concrete mix to be workable as quarry dust has a high affinity for water, creating a greater moisture suction scenario within the concrete matrix and hence the occurrence of drying shrinkage. This can be solved by prewetting the quarry dust before using it for casting purposes [53]. Furthermore, sand can help to reduce the drying shrinkage due to its filler properties in preventing the formation of water pockets inside the concrete matrix [87]. The magnified illustrations of fresh and grounded POFA are shown in Figure 9. Grounded POFA is able to slip in the gaps between coarse aggregates and undergo pozzolanic reactions [87]. Moreover, these pozzolanic reactions are able to reduce the water pockets in the concrete matrices and hence reduce the drying shrinkage, resulting in a more dense and solid concrete product.
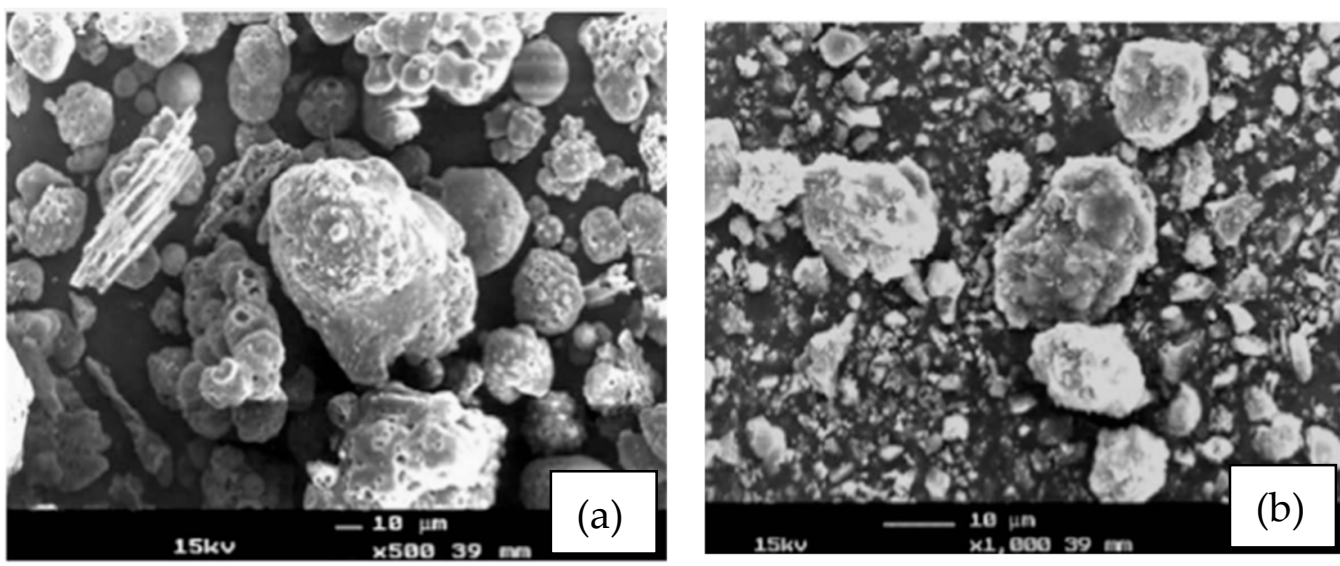

Figure 9. SEM of (a) fresh and (b) grounded POFA [87].

\subsection{Effects of Saturated Surface Dried Aggregate}

Prewetted aggregates or saturated surface dried aggregates are the methods used to saturate the inner pores of the aggregates before casting. The process is executed by soaking the aggregates for $24 \mathrm{~h}$ before drying them under the sun or any way appropriate to achieve a dry surface, as suggested by [47]. This process is proposed to prevent the alternation of the designed water content of the mixes. Full hydration may not occur if the water is consumed and attracted by aggregates. Among sun-dried aggregates, air-dried aggregates, and saturated surface dry aggregates, the insertion of saturated surface dried aggregates can produce concrete with the best mechanical properties [88]. 


\subsection{Code Specifications}

According to Malaysian standards, all mixes considered in the current study do not meet the specifications of engineering blocks. However, they are within the limit of load-bearing brick Classes 1 to 4 . For Singapore standards, these mixes comply with the common bricks of Grade 2 and 3 specifications. Generally, the proposed design mixes are only recommended for moderate weather conditions but not severe ones. This is due to the water absorption issue. Water absorption from the surrounding environment is another important performance indicator as this property may also reflect the absorbance of chemicals from the building outdoor to indoor, thus endangering its occupants. In order to address this concern, it is suggested here to apply one impermeable layer of coating to prevent the concrete from absorbing water from the surrounding environment. For a general comparison, Table 8 lists the compliances of the proposed design mixes with numerous existing codes of practice.

Table 8. Code compliance for the design mix.

\begin{tabular}{|c|c|c|c|c|c|c|c|c|}
\hline \multirow[b]{2}{*}{ Spec. } & \multirow[b]{2}{*}{ Code } & \multirow[b]{2}{*}{ Class } & \multirow{2}{*}{$\begin{array}{l}\text { Compressive } \\
\text { Stress (MPa) }\end{array}$} & \multirow{2}{*}{$\begin{array}{c}\text { Water } \\
\text { Absorption } \\
(\%)\end{array}$} & \multicolumn{4}{|c|}{ Compliance } \\
\hline & & & & & $100 \%$ RS & $\begin{array}{c}10 \% \text { QD + } \\
90 \% \text { RS }\end{array}$ & $\begin{array}{c}30 \% \text { QD + } \\
70 \% \text { RS }\end{array}$ & $\begin{array}{c}50 \% \text { QD + } \\
50 \% \text { RS }\end{array}$ \\
\hline \multirow{2}{*}{$\begin{array}{l}\text { Engineering } \\
\text { Block }\end{array}$} & \multirow{2}{*}{$\begin{array}{l}\text { Malaysian } \\
\text { Standards } \\
7.6: 1972\end{array}$} & A & 69.0 & 4.5 & $x$ & $\times$ & $\times$ & $\times$ \\
\hline & & $\mathrm{B}$ & 48.5 & 7.0 & $x$ & $x$ & $x$ & $x$ \\
\hline \multirow{8}{*}{$\begin{array}{l}\text { Load Bearing } \\
\text { Brick }\end{array}$} & \multirow{8}{*}{$\begin{array}{l}\text { Malaysian } \\
\text { Standards } \\
7.6: 1972\end{array}$} & 15 & 103.50 & - & $\times$ & $\times$ & $\times$ & $\times$ \\
\hline & & 10 & 69.0 & - & $\times$ & $\times$ & $\times$ & $\times$ \\
\hline & & 7 & 48.5 & - & $\times$ & $\times$ & $\times$ & $\times$ \\
\hline & & 5 & 34.5 & - & $\sqrt{ }$ & $\sqrt{ }$ & $\sqrt{ }$ & $\times$ \\
\hline & & 4 & 27.5 & - & $\sqrt{ }$ & $\sqrt{ }$ & $\sqrt{ }$ & $\sqrt{ }$ \\
\hline & & 3 & 20.5 & - & $\sqrt{ }$ & $\sqrt{ }$ & $\sqrt{ }$ & $\sqrt{ }$ \\
\hline & & 2 & 14.0 & - & $\sqrt{ }$ & $\sqrt{ }$ & $\sqrt{ }$ & $\sqrt{ }$ \\
\hline & & 1 & 7.0 & - & $\sqrt{ }$ & $\sqrt{ }$ & $\sqrt{ }$ & $\sqrt{ }$ \\
\hline $\begin{array}{l}\text { Damp Proof } \\
\text { Brick }\end{array}$ & $\begin{array}{c}\text { Malaysian } \\
\text { Standards } \\
7.6: 1972\end{array}$ & $\mathrm{DPC}$ & 7.0 & 4.5 & $x$ & $\times$ & $\times$ & $x$ \\
\hline \multirow{3}{*}{$\begin{array}{l}\text { Facing/Common } \\
\text { Brick }\end{array}$} & \multirow{3}{*}{$\begin{array}{l}\text { Singapore } \\
\text { Standards } \\
103: 1974\end{array}$} & 1st Grade & 35.0 & 25.0 & $\times$ & $\sqrt{ }$ & $\sqrt{ }$ & $\times$ \\
\hline & & 2nd Grade & 20.0 & 25.0 & $\sqrt{ }$ & $\sqrt{ }$ & $\sqrt{ }$ & $\sqrt{ }$ \\
\hline & & 3rd Grade & 5.2 & 25.0 & $\sqrt{ }$ & $\sqrt{ }$ & $\sqrt{ }$ & $\sqrt{ }$ \\
\hline \multirow{2}{*}{ Building Brick } & \multirow{2}{*}{ ASTM C62M } & SW & 20.7 & 17.0 & $\times$ & $\sqrt{ }$ & $\sqrt{ }$ & $\sqrt{ }$ \\
\hline & & MW & 17.2 & 22.0 & $\sqrt{ }$ & $\sqrt{ }$ & $\sqrt{ }$ & $\sqrt{ }$ \\
\hline \multirow{2}{*}{ Facing Brick } & \multirow{2}{*}{ ASTM C216M } & SW & 20.7 & 17.0 & $x$ & $\sqrt{ }$ & $\sqrt{ }$ & $\sqrt{ }$ \\
\hline & & MW & 17.2 & 22.0 & $\sqrt{ }$ & $\sqrt{ }$ & $\sqrt{ }$ & $\sqrt{ }$ \\
\hline \multirow{2}{*}{$\begin{array}{c}\text { Pedestrian } \\
\text { Traffic Paving } \\
\text { Brick }\end{array}$} & \multirow{2}{*}{ ASTM C902M } & SW & 55.2 & 8.0 & $\times$ & $\times$ & $\times$ & $\times$ \\
\hline & & MW & 20.7 & 14.0 & $x$ & $\times$ & $\times$ & $\times$ \\
\hline \multirow{2}{*}{$\begin{array}{l}\text { Load Bearing } \\
\text { Masonry }\end{array}$} & \multirow{2}{*}{ ASTM C90M } & SW & 20.7 & 17.0 & $x$ & $\sqrt{ }$ & $\sqrt{ }$ & $\sqrt{ }$ \\
\hline & & MW & 13.1 & 17.0 & $x$ & $\sqrt{ }$ & $\sqrt{ }$ & $\sqrt{ }$ \\
\hline
\end{tabular}

SW-Severe Weather, MW-Moderate Weather, $x$-no and $\sqrt{ }$-yes.

\subsection{Cost Analysis}

The preliminary costing of a brick fabrication has been calculated and compared to ordinary OPC brick. Table 9 shows the brick manufacturing cost with the proposed mix of $30 \%$ QD $+70 \%$ RS. The calculation is based on a single brick with the dimensions: a height of $65 \pm 1.875 \mathrm{~mm}$, width of $102.5 \pm 1.875 \mathrm{~mm}$, and length $215 \pm 3 \mathrm{~mm}$. Overall, the cost to fabricate a single repurposed brick is found cheaper than conventional cement brick. In addition, the beneficial properties for each brick type are included for reference. 
Table 9. Cost calculation of a single proposed brick.

\begin{tabular}{|c|c|c|c|}
\hline \multirow{7}{*}{ OPC brick } & Material & Price (USD) & Benefit \\
\hline & Cement & 0.21 & \multirow{6}{*}{$\begin{array}{l}\text { - Stronger than agro-industrial waste } \\
\text { incorporated brick } \\
\text { - } \quad \text { Less preparation time } \\
\text { - } \quad \text { Materials highly available }\end{array}$} \\
\hline & Gravel & 0.01 & \\
\hline & Sand & 0.01 & \\
\hline & Water & 0.00 & \\
\hline & Labor Cost & 0.05 & \\
\hline & Total & 0.28 & \\
\hline \multirow{9}{*}{$\begin{array}{l}\text { Proposed } \\
\text { agro-industrial waste brick }\end{array}$} & Cement & 0.09 & \multirow{9}{*}{$\begin{array}{l}\text { - Less cement powder is required for the mix as it is } \\
\text { partially replaced by POFA } \\
\text { Materials used are mostly sustainable such as } \\
\text { incorporating agro-industrial waste into the mix } \\
\text { - Lower carbon footprint in producing the } \\
\text { concrete brick } \\
\text { Lighter in weight making it convenient } \\
\text { for transportation }\end{array}$} \\
\hline & POFA & Waste & \\
\hline & Sand & 0.01 & \\
\hline & QD & 0.00 & \\
\hline & Superplasticizer & 0.01 & \\
\hline & Water & 0.00 & \\
\hline & Labor Cost & 0.05 & \\
\hline & OPS & Waste & \\
\hline & Total & 0.16 & \\
\hline
\end{tabular}

Depending on the code specifications, these investigated design mixes serve a wide range of applications for cement brick, as shown in Table 8, from non-load-bearing to load-bearing. By using local industrial wastes incorporated in the brick matrix, they are promoting a sustainable context in the construction industry. Although this green cement brick has lower strength, it is able to achieve structural use according to code specifications. For the high water absorption properties of this proposed green cement brick, it can be solved by introducing the waterproof cover on the concrete surface. As a low-density cement brick, it is also reducing the energy consumption through low heat transfer from the outdoor to the indoor environment $[30,89]$ with lower manufacturing cost, and it should have a good soundproof property due to its low concrete density.

\section{Conclusions}

This study was devoted to the mechanical and physical properties examination of concrete mix with the full replacement of coarse aggregate with OPS, 20\% of cement replacement with POFA, and different replacements of fine aggregate with QD as design mixes. Several conclusions can be drawn from the study:

- All design mixes in the second phase met the minimal structural compressive strength of $17 \mathrm{MPa}$, whereas only $30 \% \mathrm{QD}+70 \% \mathrm{RS}$ achieved the minimal tensile splitting strength of $2 \mathrm{MPa}$ for a structural requirement. The compressive strength has been improved as compared to those in [29].

- The water absorptions of all specimens were between 14.9 to $18.3 \%$, with densities of lesser than $1700 \mathrm{~kg} / \mathrm{m}^{3}$. All design mixes were effloresced where a layer of mineral salt precipitation was found within the specimens.

- It is found that the grounded POFA is able to slip in the gaps between coarse aggregates and undergo pozzolanic reactions. Moreover, these pozzolanic reactions are able to reduce the water pockets in the concrete matrices and hence reduce the drying shrinkage, resulting in a more dense and solid concrete product.

- All design mixes complied with Malaysian (load-bearing brick of Classes 1 to 4), Singapore (common brick of Grades 2 and 3), and ASTM (building and facing bricks at moderate weather conditions) specifications. 
- It is revealed that the specimens with limestone powder have experienced two phases of precipitation. This justified that the efflorescence visibility was more obvious as compared to the control specimen.

- The cost to fabricate a single brick was found almost equivalent to a conventional cement brick.

Hence, the proposed green cement brick shows good feasibility to be applied in the construction industry in promoting materials sustainability and better waste management. It is also recommended to conduct a more comprehensive testing program to assess the potential use of the new bricks, such as length change, sound, and thermal insulation properties.

Author Contributions: Conceptualization, W.Q.C. and Y.H.L.; Data curation, W.Q.C., Y.H.L., M.A., R.F., N.V., A.B.H.K. and Y.Y.L.; Formal analysis, W.Q.C., Y.H.L., M.A., R.F., N.V., A.B.H.K. and Y.Y.L.; Funding acquisition, M.A., R.F. and N.V.; Investigation, W.Q.C. and Y.H.L.; Methodology, W.Q.C., Y.H.L. and A.B.H.K.; Resources, M.A., R.F., N.V. and Y.Y.L.; Software, A.B.H.K. and Y.Y.L.; Supervision, Y.H.L.; Validation, M.A., R.F., N.V., A.B.H.K. and Y.Y.L.; Visualization, M.A. and A.B.H.K.; Writingoriginal draft, W.Q.C. and Y.H.L.; Writing-review and editing, M.A., R.F., N.V., A.B.H.K. and Y.Y.L. All authors have read and agreed to the published version of the manuscript.

Funding: The research is partially funded by the Ministry of Science and Higher Education of the Russian Federation as part of the World-class Research Center program: Advanced Digital Technologies (contract No. 075-15-2020-934 dated 17 November 2020).

Institutional Review Board Statement: Not applicable.

Informed Consent Statement: Not applicable.

Data Availability Statement: Data sharing not applicable.

Acknowledgments: The authors gratefully acknowledge the financial support given by the Department of Civil and Construction Engineering, Faculty of Engineering and Science, Curtin University, Malaysia and the Deanship of Scientific Research at Prince Sattam bin Abdulaziz University, Alkharj, Saudi Arabia, and the collaboration of the Department of Civil Engineering, Faculty of Engineering and IT, Amran University, Yemen, and Department of Civil and Construction Engineering, Curtin University Malaysia, for this research.

Conflicts of Interest: The authors declare no conflict of interest.

\section{References}

1. Herbert, T. Brick: A world history. Choice Rev. Online 2004, 41, 3863. [CrossRef]

2. Zhang, L. Production of bricks from waste materials-A review. Constr. Build. Mater. 2013, 47, 643-655. [CrossRef]

3. Makul, N.; Fediuk, R.; Amran, H.M.M.; Zeyad, A.M.; de Azevedo, A.R.G.; Klyuev, S.; Vatin, N.; Karelina, M. Capacity to develop recycled aggregate concrete in South East Asia. Buildings 2021, 11, 234. [CrossRef]

4. Sebastián, E.; Cultrone, G. Technology of rammed-earth constructions ("Tapial”) in Andalusia (Spain): Their restoration and conservation. In Materials, Technologies and Practice in Historic Heritage Structures; Dan, M.B., Přikry, R., Török, Á., Eds.; Springer: Dordrecht, The Netherlands, 2010; pp. 11-28. ISBN 978-90-481-2684-2.

5. Balaguera, A.; Carvajal, G.I.; Albertí, J.; Fullana-i-Palmer, P. Life cycle assessment of road construction alternative materials: A literature review. Resour. Conserv. Recycl. 2018, 132, 37-48. [CrossRef]

6. Murmu, A.L.; Patel, A. Towards sustainable bricks production: An overview. Constr. Build. Mater. 2018, 165, 112-125. [CrossRef]

7. Mohd Hasan, M.R.; Chew, J.W.; Jamshidi, A.; Yang, X.; Hamzah, M.O. Review of sustainability, pretreatment, and engineering considerations of asphalt modifiers from the industrial solid wastes. J. Traffic Transp. Eng. 2019, 6, 209-244. [CrossRef]

8. Jong, L.Y.; Teo, D.C.L. Concrete containing palm oil fuel ash (POFA) and oil palm shell (OPS) subjected to elevated temperatures. J. Civ. Eng. Sci. Technol. 2014, 5, 13-17. [CrossRef]

9. Amran, M.; Fediuk, R.; Murali, G.; Vatin, N.; Karelina, M.; Ozbakkaloglu, T.; Krishna, R.S.; Kumar, A.S.; Kumar, D.S.; Mishra, J. Rice husk ash-based concrete composites: A critical review of their properties and applications. Crystals 2021, 11, 168. [CrossRef]

10. Avudaiappan, S.; Prakatanoju, S.; Amran, M.; Aepuru, R.; Saavedra Flores, E.I.; Das, R.; Gupta, R.; Fediuk, R.; Vatin, N. Experimental investigation and image processing to predict the properties of concrete with the addition of nano silica and rice husk ash. Crystals 2021, 11, 1230. [CrossRef]

11. Chiang, K.Y.; Chou, P.H.; Hua, C.R.; Chien, K.L.; Cheeseman, C. Lightweight bricks manufactured from water treatment sludge and rice husks. J. Hazard. Mater. 2009, 171, 76-82. [CrossRef] 
12. Juel, M.A.I.; Mizan, A.; Ahmed, T. Sustainable use of tannery sludge in brick manufacturing in Bangladesh. Waste Manag. 2017, 60, 259-269. [CrossRef] [PubMed]

13. Kinuthia, J.M.; Nidzam, R.M. Towards zero industrial waste: Utilisation of brick dust waste in sustainable construction. Waste Manag. 2011, 31, 1867-1878. [CrossRef] [PubMed]

14. Ng, W.P.Q.; Lam, H.L.; Ng, F.Y.; Kamal, M.; Lim, J.H.E. Waste-to-wealth: Green potential from palm biomass in Malaysia. J. Clean. Prod. 2012, 34, 57-65. [CrossRef]

15. Asensio, E.; Medina, C.; Frías, M.; de Rojas, M.I.S. Characterization of ceramic-based construction and demolition waste: Use as pozzolan in cements. J. Am. Ceram. Soc. 2016, 99, 4121-4127. [CrossRef]

16. Muñoz, V.P.; Morales, O.M.P.; Letelier, G.V.; Mendívil, G.M.A. Fired clay bricks made by adding wastes: Assessment of the impact on physical, mechanical and thermal properties. Constr. Build. Mater. 2016, 125, 241-252. [CrossRef]

17. De Lassio, J.; França, J.; Espirito Santo, K.; Haddad, A. Case study: LCA methodology applied to materials management in a Brazilian residential construction site. J. Eng. 2016, 2016, 8513293. [CrossRef]

18. Kaza, S.; Yao, L.C.; Bhada-Tata, P.; Van Woerden, F. What a Waste 2.0: A Global Snapshot of Solid Waste Management to 2050; World Bank Publications: Washington, DC, USA, 2018.

19. Arrigoni, A.; Grillet, A.C.; Pelosato, R.; Dotelli, G.; Beckett, C.T.S.; Woloszyn, M.; Ciancio, D. Reduction of rammed earth's hygroscopic performance under stabilisation: An experimental investigation. Build. Environ. 2017, 115, 358-367. [CrossRef]

20. Sekhar, D.C.; Nayak, S. Utilization of granulated blast furnace slag and cement in the manufacture of compressed stabilized earth blocks. Constr. Build. Mater. 2018, 166, 531-536. [CrossRef]

21. Da Cardoso, A.C.F.; Galatto, S.L.; Guadagnin, M.R. Estimativa de geração de resíduos da construção civil e estudo de viabilidade de usina de triagem e reciclagem. Rev. Bras. Ciênc. Ambient. 2014, 31, 1-10.

22. Rodseth, C.; Notten, P.; von Blottnitz, H. A revised approach for estimating informally disposed domestic waste in rural versus urban South Africa and implications for waste management. S. Afr. J. Sci. 2020, 116, 1-6. [CrossRef]

23. Kadir, A.A.; Mohajerani, A. Bricks: An excellent building material for recycling wastes-A review. In Proceedings of the IASTED International Conference on Environmental Management and Engineering (EME 2011), Calgary, AB, Canada, 4-6 July 2011; pp. 108-115.

24. Al-Fakih, A.; Mohammed, B.S.; Wahab, M.M.A.; Liew, M.S.; Mugahed Amran, Y.H.; Alyousef, R.; Alabduljabbar, H. Characteristic compressive strength correlation of rubberized concrete interlocking masonry wall. Structures 2020, 26, 169-184. [CrossRef]

25. Lesovik, V.; Volodchenko, A.; Fediuk, R.; Mugahed Amran, Y.H.; Timokhin, R. Enhancing performances of clay masonry materials based on nanosize mine waste. Constr. Build. Mater. 2021, 269, 121333. [CrossRef]

26. Al-Fakih, A.; Mohammed, B.S.; Wahab, M.M.A.; Liew, M.S.; Mugahed Amran, Y.H. Flexural behavior of rubberized concrete interlocking masonry walls under out-of-plane load. Constr. Build. Mater. 2020, 263, 120661. [CrossRef]

27. Buyle, M.; Braet, J.; Audenaert, A. Life cycle assessment in the construction sector: A review. Renew. Sustain. Energy Rev. 2013, 26, 379-388. [CrossRef]

28. Smol, M.; Kulczycka, J.; Henclik, A.; Gorazda, K.; Wzorek, Z. The possible use of sewage sludge ash (SSA) in the construction industry as a way towards a circular economy. J. Clean. Prod. 2015, 95, 45-54. [CrossRef]

29. Raut, A.N.; Gomez, C.P. Development of thermally efficient fibre-based eco-friendly brick reusing locally available waste materials. Constr. Build. Mater. 2017, 133, 275-284. [CrossRef]

30. Lee, Y.H.; Amran, M.; Yong Lee, Y.; Hong Kueh, A.B.; Fui Kiew, S.; Fediuk, R.; Vatin, N.; Vasilev, Y. Thermal behavior and energy efficiency of modified concretes in the tropical climate: A systematic review. Sustainability 2021, 13, 11957. [CrossRef]

31. Tolstoy, A.; Lesovik, V.; Fediuk, R.; Amran, M.; Gunasekaran, M.; Vatin, N.; Vasilev, Y. Production of greener high-strength concrete using russian quartz sandstone mine waste aggregates. Materials 2020, 13, 5575. [CrossRef]

32. Da Silva, T.R.; de Azevedo, A.R.G.; Cecchin, D.; Marvila, M.T.; Amran, M.; Fediuk, R.; Vatin, N.; Karelina, M.; Klyuev, S.; Szelag, M. Application of plastic wastes in construction materials: A review using the concept of life-cycle assessment in the context of recent research for future perspectives. Materials 2021, 14, 3549. [CrossRef]

33. Lesovik, V.; Volodchenko, A.; Fediuk, R.; Mugahed Amran, Y.H. Improving the hardened properties of nonautoclaved silicate materials using nanodispersed mine waste. J. Mater. Civ. Eng. 2021, 33, 04021214. [CrossRef]

34. Petropavlovskii, K.; Novichenkova, T.; Petropavlovskaya, V.; Sulman, M.; Fediuk, R.; Amran, M. Faience waste for the production of wall products. Materials 2021, 14, 6677. [CrossRef] [PubMed]

35. De Carvalho Araújo, C.K.; Salvador, R.; Moro Piekarski, C.; Sokulski, C.C.; de Francisco, A.C.; de Carvalho Araújo Camargo, S.K. Circular economy practices on wood panels: A bibliographic analysis. Sustainability 2019, 11, 1057. [CrossRef]

36. Krishna, R.S.; Mishra, J.; Meher, S.; Das, S.K.; Mustakim, S.M.; Singh, S.K. Industrial solid waste management through sustainable green technology: Case study insights from steel and mining industry in Keonjhar, India. Mater. Today Proc. 2020, 33, 5243-5249. [CrossRef]

37. Ashour, T.; Korjenic, A.; Korjenic, S.; Wu, W. Thermal conductivity of unfired earth bricks reinforced by agricultural wastes with cement and gypsum. Energy Build. 2015, 104, 139-146. [CrossRef]

38. Yuan, X.; Tang, Y.; Li, Y.; Wang, Q.; Zuo, J.; Song, Z. Environmental and economic impacts assessment of concrete pavement brick and permeable brick production process-A case study in China. J. Clean. Prod. 2018, 171, 198-208. [CrossRef]

39. Shafigh, P.; Jumaat, M.Z.; Mahmud, H.B.; Hamid, N.A.A. Lightweight concrete made from crushed oil palm shell: Tensile strength and effect of initial curing on compressive strength. Constr. Build. Mater. 2012, 27, 252-258. [CrossRef] 
40. Amran, M.; Murali, G.; Fediuk, R.; Vatin, N.; Vasilev, Y.; Abdelgader, H. Palm oil fuel ash-based eco-efficient concrete: A critical review of the short-term properties. Materials 2021, 14, 332. [CrossRef]

41. Mosaberpanah, M.A.; Amran, Y.H.M.; Akoush, A. Performance investigation of palm kernel shell ash in high strength concrete production. Comput. Concr. 2020, 26, 577-585. [CrossRef]

42. Al-Hokabi, A.; Hasan, M.; Amran, M.; Fediuk, R.; Vatin, N.I.; Klyuev, S. Improving the early properties of treated soft kaolin clay with palm oil fuel ash and gypsum. Sustainability 2021, 13, 910. [CrossRef]

43. Amran, M.; Lee, Y.H.; Fediuk, R.; Murali, G.; Mosaberpanah, M.A.; Ozbakkaloglu, T.; Lee, Y.Y.; Vatin, N.; Klyuev, S.; Karelia, M. Palm oil fuel ash-based eco-friendly concrete composite: A critical review of the long-term properties. Materials 2021, 14, 7074. [CrossRef]

44. Zeyad, A.M.; Johari, M.A.M.; Alharbi, Y.R.; Abadel, A.A.; Amran, Y.H.M.; Tayeh, B.A.; Abutaleb, A. Influence of steam curing regimes on the properties of ultrafine POFA-based high-strength green concrete. J. Build. Eng. 2021, 38, 102204. [CrossRef]

45. Teo, D.C.L.; Mannan, M.A.; Kurian, V.J. Structural concrete using oil palm shell (OPS) as lightweight aggregate. Turk. J. Eng. Environ. Sci. 2006, 30, 251-257.

46. Mannan, M.A.; Ganapathy, C. Engineering properties of concrete with oil palm shell as coarse aggregate. Constr. Build. Mater. 2002, 16, 29-34. [CrossRef]

47. Shafigh, P.; Jumaat, M.Z.; Mahmud, H. Oil palm shell as a lightweight aggregate for production high strength lightweight concrete. Constr. Build. Mater. 2011, 25, 1848-1853. [CrossRef]

48. Shafigh, P.; Johnson Alengaram, U.; Mahmud, H.B.; Jumaat, M.Z. Engineering properties of oil palm shell lightweight concrete containing fly ash. Mater. Des. 2013, 49, 613-621. [CrossRef]

49. Shafigh, P.; Jumaat, M.Z.; Mahmud, H. Mix design and mechanical properties of oil palm shell lightweight aggregate concrete: A review. Int. J. Phys. Sci. 2010, 5, 2127-2134.

50. Aslam, M.; Shafigh, P.; Jumaat, M.Z. Oil-palm by-products as lightweight aggregate in concrete mixture: A review. J. Clean. Prod. 2016, 126, 56-73. [CrossRef]

51. Zhao, Y.; Qiu, J.; Xing, J.; Sun, X. Recycling of quarry dust for supplementary cementitious materials in low carbon cement. Constr Build. Mater. 2020, 237, 117608. [CrossRef]

52. Dhoka, M.M.C. Green concrete: Using industrial waste of marble powder, quarry dust and paper pulp. Int. J. Eng. Sci. Invent. 2013, 2, 67-70

53. Lim, J.S.; Cheah, C.B.; Ramli, M.B. The setting behavior, mechanical properties and drying shrinkage of ternary blended concrete containing granite quarry dust and processed steel slag aggregate. Constr. Build. Mater. 2019, 215, 447-461. [CrossRef]

54. Irwan, J.M.; Othman, N.; Koh, H.B. Properties of sand cement brick containing quarry dust (SCBQD) and bacteria strain. Int. J. Sustain. Constr. Eng. Technol. 2020, 11, 13-22. [CrossRef]

55. Siddika, A.; Amin, M.R.; Rayhan, M.A.; Islam, M.S.; Mamun, M.A.A.; Alyousef, R.; Mugahed Amran, Y.H. Performance of sustainable green concrete incorporated with fly ash, rice husk ash, and stone dust. Acta Polytech. 2021, 61, 279-291. [CrossRef]

56. Saheed, S.; Amran, Y.H.M.; El-Zeadani, M.; Aziz, F.N.A.; Fediuk, R.; Alyousef, R.; Alabduljabbar, H. Structural behavior of out-of-plane loaded precast lightweight EPS-foam concrete C-shaped slabs. J. Build. Eng. 2021, 33, 101597. [CrossRef]

57. Saheed, S.; Aziz, F.N.A.A.; Amran, M.; Vatin, N.; Fediuk, R.; Ozbakkaloglu, T.; Murali, G.; Mosaberpanah, M.A. Structural performance of shear loaded precast EPS-foam concrete half-shaped slabs. Sustainability 2020, 12, 9679. [CrossRef]

58. Lim, S.K.; Tan, C.S.; Li, B.; Ling, T.C.; Hossain, M.U.; Poon, C.S. Utilizing high volumes quarry wastes in the production of lightweight foamed concrete. Constr. Build. Mater. 2017, 151, 441-448. [CrossRef]

59. Febin, G.K.; Abhirami, A.; Vineetha, A.K.; Manisha, V.; Ramkrishnan, R.; Sathyan, D.; Mini, K.M. Strength and durability properties of quarry dust powder incorporated concrete blocks. Constr. Build. Mater. 2019, 228, 116793. [CrossRef]

60. Ilangovana, R.; Mahendrana, N.; Nagamanib, K. Strength and durability properties of concrete containing quarry rock dust as fine aggregate. J. Eng. Appl. Sci. 2008, 3, 20-26.

61. Hamid Mir, A. Improved concrete properties using quarry dust as replacement for natural sand. Int. J. Eng. Res. Dev. 2015, 11, 46-52.

62. ASTM C330; Standard Specification for Lightweight Aggregates for Structural Concrete. ASTM International: West Conshohocken, PA, USA, 2009. [CrossRef]

63. ASTM C33; Standard Specification for Concrete Aggregates. ASTM International: West Conshohocken, PA, USA, 2010.

64. ASTM C143/C143M; Standard Test Method for Slump of Hydraulic-Cement Concrete. ASTM International: West Conshohocken, PA, USA, 2015.

65. ASTM C172/C172M-10; Standard Practice for Sampling Freshly Mixed Concrete. ASTM International: West Conshohocken, PA, USA, 2010.

66. ASTM C140/C140M; Standard Test Methods for Sampling and Testing Concrete Masonry Units and Related Units 1. ASTM International: West Conshohocken, PA, USA, 2020.

67. ASTM C496/C496M-17; Standard Test Method for Splitting Tensile Strength of Cylindrical Concrete Specimens ASTM C-496. ASTM International: West Conshohocken, PA, USA, 2011; ISBN 5919881100.

68. ASTM C78; Standard Test Method for Flexural Strength of Concrete. ASTM International: West Conshohocken, PA, USA, 2016.

69. Sanders, J.P.; Brosnan, D.A. Test method for determining the efflorescence potential of masonry materials based on soluble salt content. J. ASTM Int. 2010, 7, 102725. [CrossRef] 
70. Singh, M.; Siddique, R. Effect of coal bottom ash as partial replacement of sand on properties of concrete. Resour. Conserv. Recycl. 2013, 72, 20-32. [CrossRef]

71. Amran, M.; Fediuk, R.; Abdelgader, H.S.; Murali, G.; Ozbakkaloglu, T.; Lee, Y.H.; Lee, Y.Y. Fiber-reinforced alkali-activated concrete: A review. J. Build. Eng. 2022, 45, 103638. [CrossRef]

72. Muthusamy, K.; Nur Azzimah, Z. Exploratory study of palm oil fuel ash as partial cement replacement in oil palm shell lightweight aggregate concrete. Res. J. Appl. Sci. Eng. Technol. 2014, 8, 150-152. [CrossRef]

73. Uysal, M.; Yilmaz, K. Effect of mineral admixtures on properties of self-compacting concrete. Cem. Concr. Compos. 2011, 33, 771-776. [CrossRef]

74. Wang, D.; Shi, C.; Farzadnia, N.; Shi, Z.; Jia, H.; Ou, Z. A review on use of limestone powder in cement-based materials: Mechanism, hydration and microstructures. Constr. Build. Mater. 2018, 181, 659-672. [CrossRef]

75. Sargent, P. The development of alkali-activated mixtures for soil stabilisation. In Handbook of Alkali-Activated Cements, Mortars and Concretes; Elsevier: Amsterdam, The Netherlands, 2015; ISBN 9781782422884.

76. Alyousef, R.; Mohammadhosseini, H.; Alrshoudi, F.; Tahir, M.M.; Alabduljabbar, H.; Mohamed, A.M. Enhanced performance of concrete composites comprising waste metalised polypropylene fibres exposed to aggressive environments. Crystals 2020, 10, 696. [CrossRef]

77. Topçu, I.B.; Uygunoğlu, T. Effect of aggregate type on properties of hardened self-consolidating lightweight concrete (SCLC). Constr. Build. Mater. 2010, 7, 1286-1295. [CrossRef]

78. Zhang, M.H.; Gjorv, O.E. Mechanical properties of high-strength lightweight concrete. ACI Mater. J. 1991, 88, 240-247. [CrossRef]

79. Babu, D.S.; Ganesh Babu, K.; Wee, T.H. Properties of lightweight expanded polystyrene aggregate concretes containing fly ash. Cem. Concr. Res. 2005, 35, 1218-1223. [CrossRef]

80. Shyam Prakash, K.; Rao, C.H. Study on compressive strength of quarry dust as fine aggregate in concrete. Adv. Civ. Eng. 2016, 2016, 1742769. [CrossRef]

81. Yew, M.K.; Bin Mahmud, H.; Ang, B.C.; Yew, M.C. Effects of oil palm shell coarse aggregate species on high strength lightweight concrete. Sci. World J. 2014, 2014, 387647. [CrossRef]

82. Aslam, M.; Shafigh, P.; Jumaat, M.Z. Drying shrinkage behaviour of structural lightweight aggregate concrete containing blended oil palm bio-products. J. Clean. Prod. 2016, 127, 183-194. [CrossRef]

83. Day, K.; Aldred, J.; Hudson, B. Properties of concrete. In Concrete Mix Design, Quality Control and Specification, 4th ed.; CRC Press: Boca Raton, FL, USA, 2013.

84. Ismail, S.; Ramli, M. Mechanical strength and drying shrinkage properties of concrete containing treated coarse recycled concrete aggregates. Constr. Build. Mater. 2014, 68, 726-739. [CrossRef]

85. Al-Jabri, K.S.; Hisada, M.; Al-Saidy, A.H.; Al-Oraimi, S.K. Performance of high strength concrete made with copper slag as a fine aggregate. Constr. Build. Mater. 2009, 23, 2132-2140. [CrossRef]

86. Aliabdo, A.A.; Abd Elmoaty, A.E.M.; Fawzy, A.M. Experimental investigation on permeability indices and strength of modified pervious concrete with recycled concrete aggregate. Constr. Build. Mater. 2018, 193, 105-127. [CrossRef]

87. Tangchirapat, W.; Jaturapitakkul, C. Strength, drying shrinkage, and water permeability of concrete incorporating ground palm oil fuel ash. Cem. Concr. Compos. 2010, 32, 767-774. [CrossRef]

88. Lee, D.T.C.; Lee, T.S. The effect of aggregate condition during mixing on the mechanical properties of oil palm shell (OPS) concrete. In Proceedings of the MATEC Web of Conferences, Amsterdam, The Netherlands, 23-25 March 2016.

89. Lee, Y.H.; Chua, N.; Amran, M.; Lee, Y.Y.; Kueh, A.H.; Fediuk, R.; Vatin, N.; Vasilev, Y. Thermal performance of structural lightweight concrete composites for potential energy saving. Crystals 2021, 11, 461. [CrossRef] 